\title{
HYPOGLYCEMIC, HEPATO-RENAL AND ANTIOXIDANT POTENTIAL EFFECTS OF CHAMOMILE RECUTITA FLOWERS ETHANOLIC EXTRACT IN STREPTOZOTOCIN-DIABETIC RATS
}

\author{
${ }^{1}$ Hassan Al-Musa and ${ }^{2}$ Fahaid AL-Hashem \\ ${ }^{1}$ Department of Family and Community Medicine, \\ College of Medicine, King Khalid University, Abha. Kingdom of Saudi Arabia \\ ${ }^{2}$ Department of Physiology, King Khalid University, College of Medicine, Abha61421, Saudi Arabia
}

Received 2013-11-20; Revised 2013-12-09; Accepted 2013-12-09

\begin{abstract}
This study was undertaken to evaluate the hypoglycemic and hepatorenal protective effect of ethanolic extract of Chamomile recutita flowers in streptozotocin-Diabetic Rats. Before the beginning of the experiments, acute and subacute studies were carried out in control animals first to investigate the LD50 of this extract. In the experimental design, adult male albino rats were divided into five groups: (1) normal control, (2) control + extract, (3) diabetic control, (4) diabetic+extract and (5) diabetic+glibenclamide $\left(200 \mu \mathrm{g} \mathrm{kg}^{-1}\right)$. The extract was given to the desired groups at a final dose of $500 \mathrm{mg} \mathrm{kg}^{-1}$ and all treatments were administered orally for 4 weeks on daily basis. Serum glucose, insulin, activities of serum marker enzymes of liver function as well as markers of kidney function was measured. The oxidative stress was assessed by measuring lipid peroxidation (TBARS) and enzyme activities of Glutathione Peroxidase (GPx) superoxide dismutase in both liver and kidney homogenates. The data showed that ethanolic flower extract of Chamomile recutita demonstrated high safety margin since the animals tolerated up to $10000 \mathrm{mg} \mathrm{kg}^{-1}$ body weight of the extract orally in the acute toxicity study and tolerated repeated doses up to $500 \mathrm{mg} \mathrm{kg}^{-1}$ for 28 days. Administration of the extract to control and diabetic rats caused significant decrease in glucose level in serum without improving insulin levels and resulted in significant increases in SOD and GPx activities with a parallel decrease in lipid peroxidation (TBARS levels) in the livers and kidneys. Furthermore, in diabetic rats, treatment with the extract resulted in significant decreases in the serum activities of liver enzymes including AST, ALT and ALP and in the levels of urea and creatinine. The hepatoprotective effect of the extract were confirmed by histological improvements in hepatic and renal tissue of the diabetic treated rats. However, the effect of the extract in diabetic rats was comparable to glibenclamide. This study demonstrates that Chamomile recutita flowers ethanolic extract has potent hypoglycemic, antioxidant and hepatorenal protective effects in diabetic rats.
\end{abstract}

Keywords: Hypoglycemic, Protective Effect, Oxidative Stress, Chamomile Recutita, Liver, Kidney

\section{INTRODUCTION}

Diabetes mellitus is a syndrome characterized by chronic hyperglycaemia and disturbances of carbohydrate, fat and protein metabolism associated with absolute or relative deficiency in insulin secretion and/or action (Akinnuga et al., 2010). Chronic elevation of blood glucose eventually leads to long-term complications of diabetes, that leads to various tissue and organs damage that considered major causes of morbidity and mortality in human populations (Lyra et al., 2006). In addition to elevated blood glucose levels, diabetes is generally accompanied with lipid metabolism abnormality communally known as diabetic dyslipidemia

Corresponding Author: Hassan Al-Musa, Department of Family and Community Medicine, College of Medicine, King Khalid University, Abha. Kingdom of Saudi Arabia 
(Zeggwagh et al., 2007). However, increased free radical generation and oxidative stress are hypothesized to play an important role in the pathogenesis of diabetes and its late complications (Zangiabadi et al., 2011). The abnormally high level of free radicals leads to membrane damage because of membrane lipids peroxidation, protein glycation and the simultaneous decline of antioxidant defence mechanisms (Zangiabadi et al., 2011).

Diet therapy along with insulin or oral hypoglycemic agent forms an important way of treatment in diabetes and its complications though it has several demerits (Dallak et al., 2009a; 2009b). The major drawbacks of insulin therapy are the side effects, which include insulin allergy, lipodystrophy and lipoatropy, insulin antibodies and resistance, altered metabolic control, placental transfer of insulin antibodies, autoimmunity and other late complications like morphological changes in kidneys and severe vascular complications (Dallak et al., 2009b; Al-Attar, 2010). Similarly, the oral hypoglycemic drugs have many side effects such as nausea and vomiting, cholestatic jaundice, agranulocytosis, aplastic and haemolytic anemias, generalized hypersensitivity reactions, dermatological reaction and lactic acidosis (Khan and Shechter, 1991). Also, the socio-economic impact of diabetes is enormous. This is especially the case in countries with limited resources. To successfully cope with this challenging situations, there is an urgent need to search for more treatment options that are readily available, safe and cost-effective.

Over the last few decades the reputation of herbal remedies has increased globally due to its therapeutic efficacy and safety. Herbal drugs are widely prescribed today despite the fact that their biologically active compounds are unknown, due to its minimal adverse effects and low costs (Dallak et al., 2009a). Traditional herbal medicines have a long history of use and are generally considered to be safer than synthetic drugs. Traditional medicine inspired approaches remain important especially for the management of chronic diseases as well as to facilitate natural product drug discovery (Dallak et al., 2009a). The potential role of the medicinal plants as antidiabetic agents has been reviewed by several authors, supported by the ethno botanical surveys and traditional medicines of different cultures. Various parts of herbs have been used for medicinal purpose including the treatment of diabetes mellitus (Dallak et al., 2009a). One such medicinal plant that is widely used in traditional medicine to manage diabetes is Chamomile recutita (Srivastava and Gupta, 2007; Singh et al., 2011).

Chamomile recutita (family Asteraceae), popularly known as Chamomile is a reputed medicinal and aromatic plant used in both traditional and modern system of medicine (Gupta and Misra, 2006). It is an ingredient of several traditional medicinal preparations and considered one of the most ancient medicinal herbs known in ancient Egypt, Greek and Rome (Srivastava and Gupta, 2007). It has been widely used as a herbal tea all over the world (Singh et al., 2011). Latterly, chamomile has been well known for its pharmaceutical properties such as anti-inflammatory, immunemodulatory activity, anticancer, arcaricidal property and antipruritic effect (Gupta and Misra, 2006; Srivastava and Gupta, 2007; Singh et al., 2011). In diabetic animal model, recent studies concentrated on chamomile tea drink and recorded that it ameliorates the hyperglycemia and diabetic complications via suppressing blood sugar levels and increasing liver glycogen storage (Kato et al., 2008). The pharmacological activity of other chamomile species extract has shown to be independent on insulin secretion (Eddouks et al., 2005) and further studies reveal protective effect on pancreatic beta cells in diminishing hyperglycemiarelated oxidative stress (Cemek et al., 2008).

Although the use of Chamomile recutita is widely common, the toxicological evaluation of this plant is lacking in literature. Also, the hypoglycemic and protective role of it ethaonlic extract never investigated before in diabetic animals or patients. Even more, the effect of chamomile recutita on the structure of diabetic liver and kidney is almost missing in literature. In a promising separate study, ethaonlic extract of chamomile has shown to have hepatoprotective activity against paractamol induced liver (Gupta and Misra, 2006). Accordingly, in the present study, the toxicological evaluation of ethanolic extract of Chamomile recutita in control normal rats and its hypoglycemic and correcting hepatic and renal antioxidant status with their associated pathological changes in streptozotocin induced diabetic rat model were studied.

\section{MATERIALS AND METHODS}

\subsection{Animals}

The experiments were performed on healthy male Wistar rats of eight weeks old and body weight of 160$200 \mathrm{~g}$. They were supplied from the animal house at the college of medicine of King Khalid University. The rats were fed with standard laboratory diets, given water ad libitum and maintained under laboratory conditions of temperature $22^{\circ} \mathrm{C}\left( \pm 3^{\circ} \mathrm{C}\right)$, with $12 \mathrm{~h}$ light and $12 \mathrm{~h}$ dark cycle. The experimental procedures involving the handling and treatment of animals were approved by the ethical committee of the medical college at King Khalid University and all procedures were conducted in 
accordance with the National Institute of Health's Guide for the Care and Use of Laboratory Animals.

\subsection{Extraction of Test Material}

The fresh flowers of Chamomile Recutita were washed; air dried and grounded to form fine powder. An amount of $5.0 \mathrm{~kg}$ of the powder was then soaked in $70 \%$ ethanol $(1.5$ L) for three days at room temperature (Gupta and Misra, 2006). The extraction procedure was repeated twice using the same powder. The filtrates from each extraction were mixed and the excess solvent was evaporated under reduced pressure, using a rotary evaporator. The total residue $(200.45 \mathrm{~g})$ was used later in the experimental procedure.

\subsection{Acute Oral Toxicity Test}

The acute oral toxicity of the ethanolic extracts of Chamomile Recutita was evaluated in rats using the procedures described by Organization for Economic Cooperation and Development 423 guidelines (OECD, 2002). A total of 40 male and females rats were divided into our dosage groups with 10 animals per dose $(5$ males and 5 females). The control group was given $10 \mathrm{~mL} \mathrm{~kg}^{-1}$ of normal saline. The second, third and fourth groups were given with a single dose of 2000, 5000 and $10000 \mathrm{mg} \mathrm{kg}^{-1}$ of C. Chamomile Recutita, respectively. Gavage dosing was performed using a curved, ball-tipped intubation needle affixed to a $5 \mathrm{~mL}$ syringe. All solutions were prepared just prior to dosing and were kept chilled and tightly capped. Body weight, food and water consumption were monitored daily. Animals were fasted approximately $12 \mathrm{~h}$ prior to dosing. Following administration of a single dose of herbal preparation, the animals were observed for behavioural changes and general toxicity signs. Results were recorded for the first $30 \mathrm{~min}$ and at hourly intervals for the next $24 \mathrm{~h}$ and thereafter for a total of 14 days. Body weight was recorded on Day 0 (before dosing), Day 7 and Day 14.

\subsection{Procedure of Subacute Oral Toxicity Test}

Repeated dose oral toxicity study was carried out according to OECD Guideline 407 (OECD, 2008). The animals were divided into four groups of 10 animals each (5 males and 5 females). Group 1 received $10 \mathrm{~mL}$ $\mathrm{kg}^{-1}$ body weight of normal saline and served as control. Groups 2, 3 and 4 received extract doses of 125, 250 and $500 \mathrm{mg} \mathrm{kg}^{-1}$ body wt, respectively. Mortality, body weight food and water consumption as well as observation for general toxicity signs of the animals were evaluated daily for 28 days.

\subsection{Induction of Diabetes}

Diabetes was introduced to rats by a single i.v., dose of streptozotocin (Sigma, St Louis, Mo, USA) into the tail vein at a dose of $65 \mathrm{mg} \mathrm{kg}^{-1}$ body weight (Zeggwagh et al., 2007). streptozotocin was extemporaneously dissolved in $0.1 \mathrm{M}$ cold sodium citrate buffer, $\mathrm{pH} 4.5$. The rats were then kept for the next $24 \mathrm{~h}$ on $5 \%$ glucose solution bottles in their cages to prevent hypoglycaemia. After 3 days, animals with fasting blood glucose levels greater than $300 \mathrm{mg} \mathrm{dL}^{-1}$ were considered diabetic and then included in this study.

\subsection{Experimental Design}

Normal and diabetic rats was randomly assigned to five groups ( $\mathrm{n}=10$ in each group) as follows:

- Control group: were non diabetic rats and received normal saline $\left(10 \mathrm{~mL} \mathrm{~kg}^{-1}\right)$

- Chamomile recutita treated group: were normal rats received the ethanolic extract of Chamomile recutita at a dose of $500 \mathrm{mg} \mathrm{kg}^{-1} \mathrm{BW}$

- Diabetic model group: were diabetic rats and received normal saline $\left(10 \mathrm{mg} \mathrm{kg}^{-1}\right)$

- Diabetic standard group: Were diabetic rats and received Glibenclamide $\left(200 \mu \mathrm{g} \mathrm{kg}^{-1}\right)$ (Kim et al., 2006)

- Diabetic treated group: were diabetic rats and received Chamomile recutita ethanolic extract at a dose of $500 \mathrm{mg} \mathrm{kg}^{-1} \mathrm{BW}$

Dose selection of Chamomile recutita was based the safe doses of Chamomile Recutita oral acute and subacute toxicity studies carried out earlier in this study. All treatments were continued or 4 weeks on daily basis. Treatments were given to all groups orally with the help of feeding cannels. At the end of day 28 and after overnight fasting, rats of all groups were anaesthetized using ether. Blood samples were immediately taken from the heart and placed in plain tubes to clot at room temperature. Following centrifugation at $4000 \mathrm{rpm}$ for 10 min, serum was collected and stored at $-20^{\circ} \mathrm{C}$ until further biochemical analysis. Immediately after blood collection, animals were killed by decapitation. Livers and kidneys were quickly collected, washed with Phosphatebuffered Saline (PBS), $\mathrm{pH} 7.4$, containing 0.16 $\mathrm{mg} \mathrm{mL} \mathrm{m}^{-1}$ of heparin to remove any red blood cells (erythrocytes) and clots. Then they were homogenized with an ultrasonic homogenizer in cold phosphate buffer, pH 7.0 with Ethylenediaminetetraacetic Acid (EDTA), for Thiobarbituric Acid Reactive Substances (TBARS) measurement and with cold $20 \mathrm{mM} \mathrm{N}$-(2-hydroxyethyl) piperazine-N'-2-ethanesulfonic acid (HEPES) buffer, $\mathrm{pH}$ 7.2, containing $1 \mathrm{mM}$ ethyleneglycol-bis (2aminoethoxy)-Tetraacetic Acid (EGTA), $210 \mathrm{mM}$ 
mannitol and $70 \mathrm{mM}$ sucrose for SOD activity measurements. Also, other parts of the kindeys and livers were homogenized in cold buffer consists of $50 \mathrm{mM}$ tris$\mathrm{HCl}, \mathrm{pH} 7.5,5 \mathrm{mM}$ ED-TA, $1 \mathrm{nM}$ DTT for Glutathione Peroxidise (GPx) activity analysis. All supernatants were kept in separate tubes and stored at -20 .

\subsection{Serum Biochemical Analysis}

Serum samples were analyzed for levels serum glucose insulin, total protein, urea, creatinine and the Activities of Alanine Aminotransferase (ALT), Aspartate Aminotransferase (AST), gamma Glutamyltransferase (GGT) and Alkaline Phosphatase (ALP). All analyses were performed with commercially kits (Human diagnostic, Germany). Insulin levels were determine by special rat ELISA determination Kit (Cat. No. 589501, Caymen chemical, USA).

\subsection{Measurement of Thiobarbituric Reactive Substances (TBARS) Levels}

Acid

Lipid peroxidation levels in liver and kindeny homogenates were measured by the Thiobarbituric Acid (TBA) reaction. This method was used to measure spectrophotometrically the color produced by the reaction of TBA with Malondialdehyde (MDA) at 532 $\mathrm{nm}$. For this purpose, TBARS levels were measured using a commercial assay as the Malondialdehyde Assay (Cat No. NWK-MDA01) supplied from NWLSS, USA. In breif, Tissue supernatant $(50 \mu \mathrm{L})$ were added to test tubes containing $2 \mu \mathrm{L}$ of Butylated Hydroxytoluene (BHT) in methanol. Next, $50 \mu \mathrm{L}$ of acid reagent (1 $\mathrm{M}$ phosphoric acid) was added and finally $50 \mu \mathrm{L}$ of TBA solution was added. The tubes were mixed vigorously and incubated for $60 \mathrm{~min}$ at $60^{\circ} \mathrm{C}$. The mixture was centrifuged at $10,000 \times \mathrm{g}$ for 3 min. The supernatant was put into wells on a microplate in aliquots of $75 \mu \mathrm{L}$ and its absorbance was measured with a plate reader at $532 \mathrm{~nm}$. TBARS (MDA) levels were expressed as nmol/mg protein.

\subsection{Measurement of Superoxide Dismutase (SOD) Activity}

SOD activity in liver and kidney homogenates was measured using a commercially assay kit (Cat NO.706002) supplied from Caymen chemical according to the manufacturer's instructions. The SOD assay consisted of a combination of the following reagents: 0.3 $\mathrm{mM}$ xanthine oxidase, $0.6 \mathrm{mM}$ diethylenetriamine-penta acetic acid (DETAPAC), $150 \mu \mathrm{M}$ Nitroblue Tetrazolium (NBT), $400 \mathrm{mM}$ sodium carbonate $(\mathrm{Na} 2 \mathrm{CO} 3)$ and bovine serum albumin $\left(1 \mathrm{~g} \mathrm{~L}^{-1}\right)$. The principle of the method is based on the inhibition of NBT reduction by superoxide radicals produced by the xanthine/xanthine oxidase system. For the assay, standard SOD solutions and tissue supernatant $(10 \mu \mathrm{L})$ were added to wells containing $200 \mu \mathrm{L}$ of NBT solution that was diluted by adding $19.95 \mathrm{~mL}$ of $50 \mathrm{mM}$ Tris- $\mathrm{HCl}, \mathrm{pH}$ 8.0, containing $0.1 \mathrm{mM}$ DETAPAC solution and $0.1 \mathrm{mM}$ hypoxanthine. Finally, $20 \mu \mathrm{L}$ of xanthine oxidase was added to the wells at an interval of $20 \mathrm{~s}$. After incubation at $25^{\circ} \mathrm{C}$ for $20 \mathrm{~min}$, the reaction was terminated by the addition of $1 \mathrm{~mL}$ of $0.8 \mathrm{mM}$ cupric chloride. The formazan was measured spectrophotometrically by reading the absorbance at $560 \mathrm{~nm}$ with the help of plate reader. One Unit (U) of SOD is defined as the amount of protein that inhibits the rate of NBT reduction by $50 \%$. The calculated SOD activity was expressed as $\mathrm{U} / \mathrm{mg}$ protein.

\subsection{Measurement of Glutathione Peroxidase (GPx) Activity}

Glutathione peroxidase activity in liver and kidney homogenates was measured using the Glutathione Peroxidase Assay Kit (Cat NO.703102, Caymen chemicals, USA) provided by Caymen chemical as per manufacture instructions. Glutathione peroxidase catalyzes the reduction of hydroperoxides, including hydrogen peroxide, by reduced glutathione and functions to protect the cell from oxidative damage. With the exception of phospholipid hydroperoxide GPX, a monomer, all of the GPX enzymes are tetramers of four identical subunits. Each subunit contains a selenocysteine in the active site, which participates directly in the two-electron reduction of the perox-ide substrate. The enzyme uses glutathione as the ultimate electron donor to regenerate the reduced form of the selenocysteine. The Cayman Chemical Glutathione Per-oxidase Assay Kit measures GPx activity indirectly by a coupled reaction with Glutathione Reductase (GR). Oxidized Glutathione (GSSG) is produced upon reduction of hydroperoxide by GPX and is recycled to its reduced state by GR and NADPH. The oxidation of NADPH to NADP+is accompanied by a decrease in absorbance at $340 \mathrm{~nm}$. Under conditions in which the GPX activity is rate limiting, the rate of decrease in the A340 is directly proportional to the GPX activity in the sample. The results were presented as nmol/g protein. One unit is defined as the amount of enzyme that causing the oxidation of $0.1 \mathrm{nmol}$ of $\mathrm{NADPH}$ to $\mathrm{NADP}^{+} / \mathrm{min}$ at $25^{\circ} \mathrm{C}$. 


\subsection{Histopathological Studies}

Small specimens of both kidneys and livers from all groups were fixed in $10 \%$ neutral buffered formalin, dehydrated in ascending concentrations of ethylalcohol (70-100\%) and then prepared using standard procedures for Hematoxylin and Eosin staining.

\subsection{Statistical Analysis}

Statistical analyses were performed by using Graphpad prism statistical software package (version 6). Data are presented as means with their standard Deviation (mean $\pm \mathrm{SD}$ ). Normality and homogeneity of the data were confirmed before ANOVA, differences among the experimental groups were assessed by oneway ANOVA followed by Tukey's t test.

\section{RESULTS}

\subsection{Subacute Oral Toxicity}

The acute toxicity study showed that animals fed by oral gavages tolerated the limit dose of $10000 \mathrm{mg} \mathrm{kg}^{-1}$ body weight of ethanolic extract of Chamomile recutita flowers. There were no visible signs of acute toxicity during the 14 days of observation. Absence of death at all doses up to $10000 \mathrm{mg} \mathrm{kg}^{-1}$ showed that the LD50 of the extract is greater than $10000 \mathrm{mg}$ extract $\mathrm{kg}^{-1}$ body weight. The daily eating and drinking habit and weekly weight gain of all the animals received the three different doses of the ethanolic extract were normal. The results obtained on the average water and food intake and weekly weight gain are presented in Table 1.

\subsection{Subacute Oral Toxicity}

No behavioural changes and death were observed at the end of the treatment period at all tested doses $\left(125,250\right.$ and $\left.500 \mathrm{mg} \mathrm{kg}^{-1}\right)$ in the subacute study. Similarly, no significant differences in daily water or food intake and weekly weight gain were observed between control and all Chamomile recutita treated groups during this period Table 2.

\subsection{Serum Glucose and Insulin Levels}

Results of the effect of daily treatment of ethanoic extract of Chamomile recutita flowers $\left(500 \mathrm{mg} \mathrm{kg}^{-1}\right)$ for 4weeks on blood glucose and insulin levels in normal and diabetic rats of experimental rats are presented in Table 3. Oral administration o the extract to control normal rats resulted in a significant decrease in serum glucose levels $(p=0.0021)$ without any significant change in serum insulin levels $(p=0.986)$. The serum glucose levels of diabetic rat model were significantly higher $(p<0.0001)$ and serum insulin levels were significantly lower $(\mathrm{p}=0.0011)$ as compared with those corresponding values of the control group. Streptozotocin administration resulted in 2.56 folds increase in serum glucose levels and $74.2 \%$ decrease in serum insulin levels. On the other hand, Chamomile recutita $\left(500 \mathrm{mg} \mathrm{kg}^{-1}\right)$ and glibenclamide treated $(200 \mu \mathrm{g}$ $\mathrm{kg}^{-1}$ ) diabetic groups showed significant decreases in blood glucose levels toward normal value as compared to diabetic model group. When compared to diabetic model group, glibenclamide caused $59.2 \%$ decrease and $145.6 \%$ increase in serum glucose and insulin levels, respectively, while ethanolic extract of Chamomile recutita resulted only in $64.5 \%$ decreases in serum glucose levels without any significant improvement in serum insulin levels which remained significantly low as compared to control rats but not signicantly different when compared to diabetic model group. The ANOVA analysis revealed that glucose levels in both Chamomile recutita and glibenclamide treated diabetic rats remained significantly higher than control group but the effect of the extract is more potent to that of glibenclamide Table 3 .

\subsection{Markers of liver and Kidney Function}

Table 4 show the effects of Chamomile recutita on the serum levels and activities of markers of liver injury (ALT, AST, ALP) in all groups of rats. No significant changes in the activities of ALT, AST and ALP were seen in the control normal rats treated with the ethanolic extract $\left(500 \mathrm{mg} \mathrm{kg}^{-1}\right)(\mathrm{p} \geq 0.05)$. However, the activities of ALT, AST, ALP were significantly elevated $(\mathrm{p}<0.05)$ in streptozotocin diabetic rats by 105,72 and $66.3 \%$, respectively when compared with the normal controls rats. On the other hand, Rats administrated ethanolic extract of Chamomile recutita or for 28 days showed significant reduction $(\mathrm{p}<0.05)$ in these marker enzyme activities to normal levels which were not significantly different when compared to control rats. Although glibenclamide resulted in significant decreases in the activities of these enzymes, their levels remained signicantly higher as compared to control group and diabetic rats treated with the extract.

However, kidney function markers including serum creatinine, urea and total protein were within normal levels in Chamomile recutita treated normal rats (Table 5). Serum creatinine and urea and levels were significantly increased by 158 and $180 \%$ respectively and serum protein levels level was decreased by $49 \%$ in diabetics rats as compared to controls. 
Hassan Al-Musa and Fahaid AL-Hashem / American Journal of Pharmacology and Toxicology 9 (1): 1-12, 2014

Table 1. Average daily drinking and food pattern and weekly weight gain in the animals used in the acute toxicity study of Chamomile recutita

\begin{tabular}{lllll}
\hline Parameter & Control & $2000 \mathrm{mg} \mathrm{Kg}$ & $5000 \mathrm{mg} \mathrm{kg}^{-1}$ & $10000 \mathrm{mg} \mathrm{kg}^{-1}$ \\
\hline Average water intake $(\mathrm{mL} /$ day) & $29.78 \pm 2.45$ & $28.56 \pm 3.10$ & $30.13 \pm 2.98$ & $28.77 \pm 3.18$ \\
Average food intake (g/day & $18.87 \pm 1.98$ & $19.03 \pm 2.34$ & $18.06 \pm 1.07$ & $19.25 \pm 2.35$ \\
Average weekly wight gain $(\mathrm{g}$ & $12.34 \pm 1.29$ & $13.10 \pm 1.73$ & $11.24 \pm 2.31$ & $13.12 \pm 2.34$ \\
\hline
\end{tabular}

Values are given as mean $\pm \mathrm{SD}(\mathrm{n}=10)$

Table 2. Average daily drinking and food consumption and weekly weight gain in the animals used in the subacute toxicity study of Chamomile recutita

\begin{tabular}{lllll}
\hline Parameter & Control & $2000 \mathrm{mg} \mathrm{Kg}^{-1}$ & $5000 \mathrm{mg} \mathrm{kg}^{-1}$ & $10000 \mathrm{mg} \mathrm{kg}^{-1}$ \\
\hline Average water intake (mL/day) & $26.32 \pm 3.18$ & $25.21 \pm 2.31$ & $24.89 \pm 1.78$ & $23.58 \pm 2.13$ \\
Average food intake (g/day) & $17.56 \pm 2.08$ & $16.67 \pm 3.11$ & $17.82 \pm 1.98$ & $18.34 \pm 3.16$ \\
Average weekly wight gain (g) & $10.78 \pm 0.98$ & $11.28 \pm 1.20$ & $10.89 \pm 2.31$ & $11.09 \pm 1.04$ \\
\hline
\end{tabular}

Values are given as Mean \pm SD $(n=10)$

Table 3. Serum glucose and insulin levels in the serum of the control and all experimental groups

\begin{tabular}{lll} 
& Serum glucose $(\mathrm{mg} / \mathrm{dL})$ & Serum Insulin $(\mathrm{ng} / \mathrm{mL})$ \\
\hline Control & $87.87 \pm 5.67$ & $1.212 \pm 0.085$ \\
Control+ Chamomile recutita $\left(500 \mathrm{mg} \mathrm{kg}^{-1}\right)$ & $74.67 \pm 4.87^{\mathrm{a}}$ & $1.192 \pm 0.072$ \\
Diabetic control & $310.34 \pm 18.98^{\mathrm{ab}}$ & $0.311 \pm 0.017^{\mathrm{ab}}$ \\
Diabetic + glibenclamide $\left(200 \mu \mathrm{g} \mathrm{kg}^{-1}\right)$ & $126.45 \pm 8.29^{\mathrm{abc}}$ & $0.764 \pm 0.012^{\mathrm{abc}}$ \\
Diabetic + Chamomile recutita $\left(500 \mathrm{mg} \mathrm{kg}^{-1}\right)$ & $110.98 \pm 7.56^{\mathrm{abcd}}$ & $0.331 \pm 0.081^{\mathrm{abd}}$ \\
\hline
\end{tabular}

Values are given as Mean \pm SD and considered siniicant at $\mathrm{p} \leq 0.05$. a: Significantly different when compared to control group. $\mathrm{b}$ : significantly different when compared to to Ccontrol+ Chamomile recutita treated group. c: significantly different when compared to diabetic model group. d: significantly different when compared to diabetic+ glibenclamide treated group

Table 4. Activities of ALT, AST and ALP in the serum of the control and all experimental groups

\begin{tabular}{lllc} 
& ALT (U/L) & AST (U/L) & ALP(U/L) \\
\hline Control & $32.12 \pm 3.65$ & $47.89 \pm 3.45$ & $92.35 \pm 7.89$ \\
Control+ Chamomile recutita $\left(500 \mathrm{mg} \mathrm{kg}^{-1}\right)$ & $33.19 \pm 2.65$ & $45.78 \pm 4.13$ & $91.24 \pm 7.83$ \\
Diabetic control & $65.89 \pm 4.12^{\mathrm{ab}}$ & $81.34 \pm 6.71^{\mathrm{ab}}$ & $153.2 \pm 12.67^{\mathrm{ab}}$ \\
Diabetic+glibenclamide $\left(200 \mu \mathrm{g} \mathrm{kg}^{-1}\right)$ & $38.63 \pm 2.89^{\mathrm{abc}}$ & $56.39 \pm 3.68^{\mathrm{abc}}$ & $112.8 \pm 9.17^{\mathrm{abc}}$ \\
Diabetic+Chamomile recutita $\left(500 \mathrm{mg} \mathrm{kg}^{-1}\right)$ & $33.41 \pm 3.72^{\mathrm{cd}}$ & $48.12 \pm 3.91^{\mathrm{cd}}$ & $94.23 \pm 3.12^{\mathrm{cd}}$ \\
\hline
\end{tabular}

Values are given as Mean \pm SD and considered siniicant at $\mathrm{p} \leq 0.05$. a: Significantly different when compared to control group. b: significantly different when compared to to Ccontrol+ Chamomile recutita treated group. c: significantly different when compared to diabetic model group. d: significantly different when compared to diabetic+ glibenclamide treated group

Table 5. Levels of Urea, Creatinine and total proteins in the serum of control and all experimental groups

\begin{tabular}{llll}
\hline & Urea $(\mathrm{mg} / \mathrm{dL})$ & Creatinine $(\mathrm{mg} / \mathrm{dL})$ & Total proteins $(\mathrm{mg} / \mathrm{dL})$ \\
\hline Control & $29.35 \pm 2.54$ & $0.742 \pm 0.022$ & $6.75+0.84$ \\
Control+Chamomile recutita $\left(500 \mathrm{mg} \mathrm{kg}^{-1}\right)$ & $27.87 \pm 1.03$ & $0.658 \pm 0.011$ & $6.81 \pm 0.97$ \\
Diabetic control & $75.65 \pm 6.34^{\mathrm{ab}}$ & $2.08 \pm 0.056^{\mathrm{ab}}$ & $3.45 \pm 0.34^{\mathrm{ab}}$ \\
Diabetic+glibenclamide $\left(200 \mu \mathrm{g} \mathrm{kg}^{-1}\right)$ & $28.24 \pm 3.12^{\mathrm{c}}$ & $0.792 \pm 0.012^{\mathrm{c}}$ & $6.53 \pm 0.36^{\mathrm{c}}$ \\
Diabetic+Chamomile recutita $\left(500 \mathrm{mg} \mathrm{kg}^{-1}\right)$ & $27.8 .23 \pm 2.36^{\mathrm{c}}$ & $0781 \pm 0.031^{\mathrm{c}}$ & $6.71 \pm 0.59^{\mathrm{c}}$
\end{tabular}

Values are given as Mean \pm SD and considered siniicant at $\mathrm{p} \leq 0.05$. a: Significantly different when compared to control group. b: significantly different when compared to to Ccontrol+ Chamomile recutita treated group. c: significantly different when compared to diabetic model group

When diabetic rats were treated with ethanolic extract or glibenclamide, a significant normalization of these parameters was observed, as compared to untreated diabetic rats (Table 5). The administration of the ethanolic extract to diabetic rats resulted in normal serum levels of creatinine, urea protein as compared to diabetic control rats. NO significant changes between the levels of these markers were detected 
between diabetic rats treated with the extract or glibenclamide (Table 5).

\subsection{Markers of Liver and Kidney Oxidative Stress}

Table 6 and 7 show the levels of lipid peroxidation markers (TBARS) and activities of superoxide dismutase (SOD) and Glutathione Peroxidise (GPx); indices of protein oxidative damage in the liver and kidney tissue of normal and experimental animals. Significant decrease in the levels of TBARS and significant increases in the activities of SOD and GPx were seen in both the liver and the kidney of normal rats treated with the ethanolic extract of Chamomile recutita as compared to control rats treated with normal saline. However, TBARS levels were significantly increased in the kidney and livers of diabetic group when compared to the control group $(\mathrm{p}<0.0001)$. Oral administration of Chamomile recutita to the diabetic rats showed a significant decrease in TBARS levels in the liver and kidney tissues by 45 and $48 \%$, respectively as compared to diabetic rats. Activities of SOD and GPX, were significantly decreased in the diabetic group when compared to the control group $(p<0.05)$. Diabetic rats administered with the ethanolic extract showed a significant increase in the activities of SOD and GPx by 92.2 and $44 \%$, in liver tissue and by 114.5 and $63 \%$ in kidney tissue respectively as compared to diabetic rats (Fig. 1 and 2, respectively). Similarly, glibenclamide treatment to diabetic rats resulted in amelioration the levels of TBARS and activities of SOD and GPx in both liver and kidney tissues of those diabetic rats. The ANOVA test showed that the effect of the extract on amelioration these oxidative stress parameters was significantly and more potent in extract treated diabetic rats as compared to glibenclamide treated diabetic rats.

\subsection{Histopathogical Findings of Liver and Kidney}

Liver histological structure was normal in healthy control and Chamomile recutita treated groups and there were no pathological changes so that hepatic lobular structure seemed quite normal with intact hepatocytes radiating from the central vein (Fig. 1). However, diabetic rats showed fatty changes in centrilobular portions of the livers with abnormal deformed hepatocytes and obvious small and large fat granules. Fat vacuoles were found in more than $80 \%$ of hepatocytes. On the other hand, oral administration of Chamomile recutita ethanolic extract or glibenclamide prevented the pathologic changes and normal architecture with no considerable fatty change was observed.
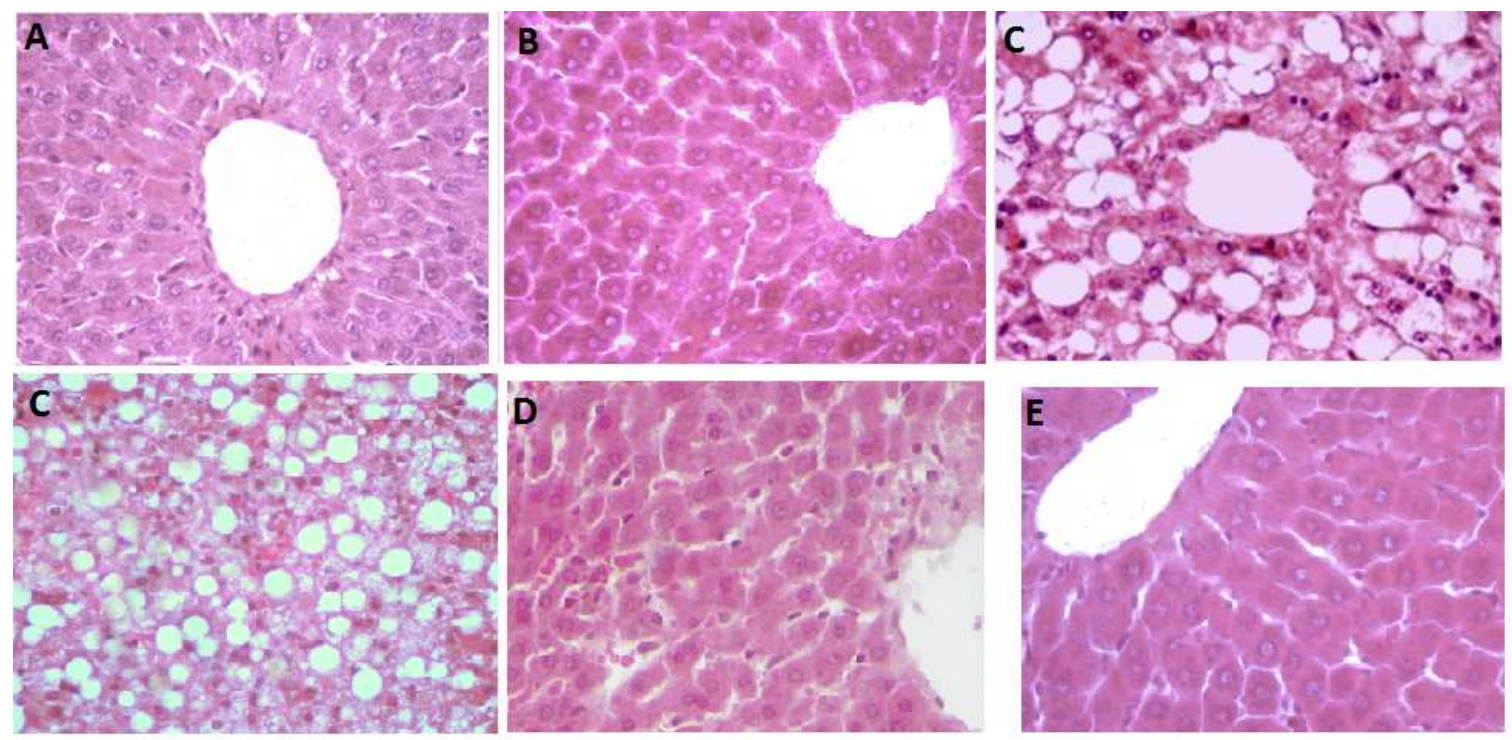

Fig. 1. Photomicrographs of livers from all groups of rats, (A) Control rat, (B) Chamomile recutita treated rat, these groups show normal liver morphology, structure and architecture with intact hepatocytes radiating from the central vein, (C) Diabetic model rat shows fatty changes in centrilobular portions of the livers with abnormal lobular structure and deformed hepatocytes with obvious small and large fat granules, (D) Glebinclamide treated diabetic rat show absence of fat vacuoles but degeneration and arrangement of hepatocytes and loss of normal lobular structure are still seen, (E) Chamomile recutita treated diabetic rat shows normal arrangement of the normal size hepatocytes with complete absence of fat vacuoles in hepatocytes.and the hepatocytes look normal radiating from the central vein 

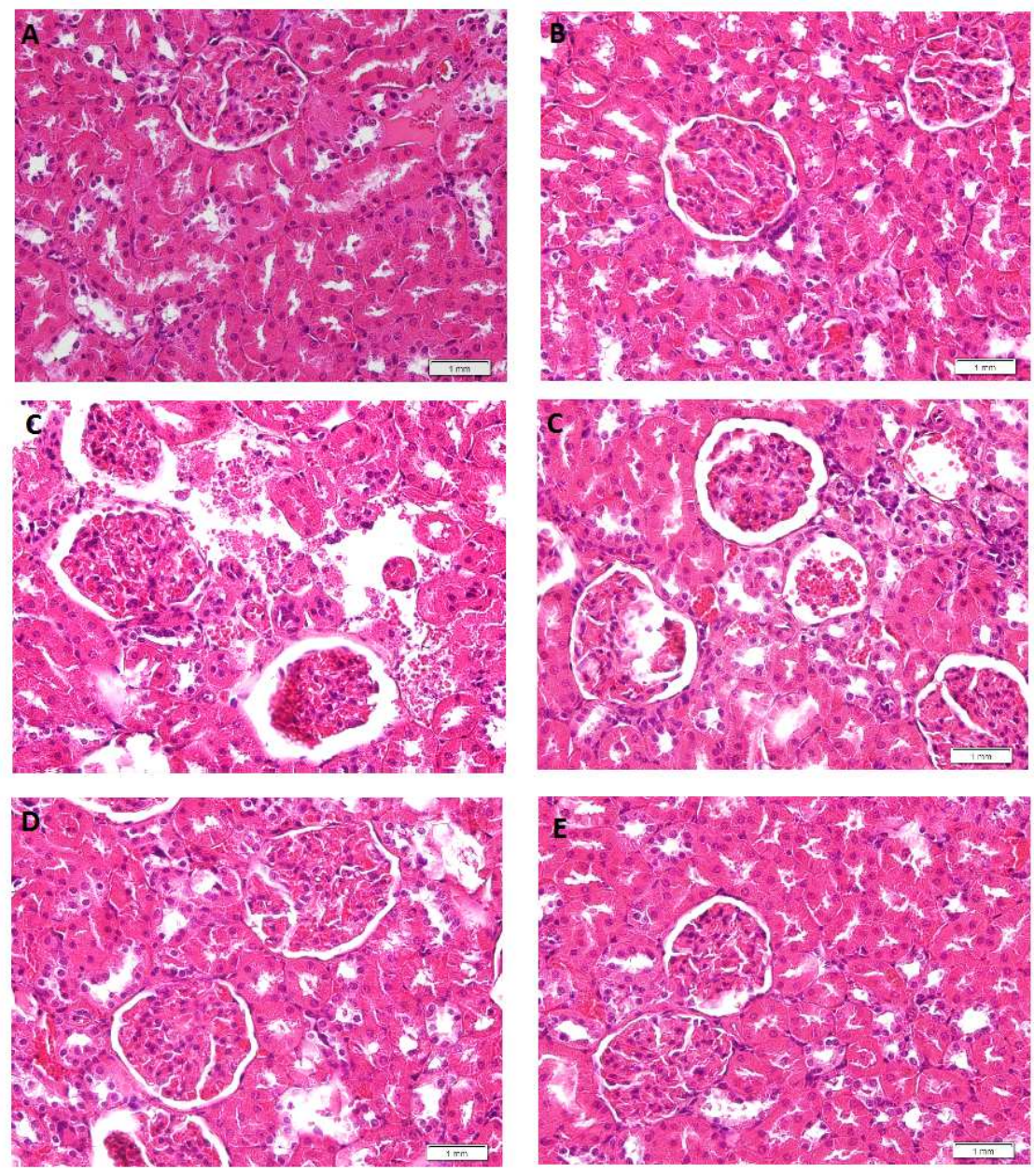

Fig. 2. Photomicrographs of kidneys from all groups of rats, (A) control rat, (B) Chamomile recutita treated rat, these groups show normal architecture of kidney with prominent Bowman's capsule, epithelial Cells and normal tubules, (C) Diabetic model rat shows mild thickening of the basement membrane along with mild change in the density of mesenchyme, atrophy and degeneration of glomerular capillaries with increased Bowman's space (urinary space) and tubular necrosis. Some of the glumerulular capillaries were completely absent, (D) Glebinclamide treated diabetic rat shows normal archeticture of glomerular capillaries, intact epithelial cells with the presence of some degeneration in the tubules, (E) Chamomile recutita treated diabetic rat shows normal kidney architecture with intact epithelial cell and tubules

Table 6. Levels of TBARS and activities of Superoxide Dismutase (SOD) and Glutathione Peroxidise (GPx) in the livers of the control and experimental groups of rats

\begin{tabular}{llll}
\hline & TBARS $(\mathrm{mmoL} / \mathrm{mg})$ & SOD $(\mathrm{U} / \mathrm{mg})$ & $\mathrm{GPx}(\mathrm{mmoL} / \mathrm{min} / \mathrm{mL})$ \\
\hline Control & $1.02 \pm 0.032$ & $10.86 \pm 1.05$ & $55.34+5.71$ \\
Control+Chamomile recutita $\left(500 \mathrm{mg} \mathrm{kg}^{-1}\right)$ & $0.85 \pm 0.012^{\mathrm{a}}$ & $14.56 \pm 1.56^{\mathrm{a}}$ & $64.34 \pm 5.89^{\mathrm{a}}$ \\
Diabetic control & $2.36 \pm 0.113^{\mathrm{ab}}$ & $4.67 \pm 1.45^{\mathrm{ab}}$ & $36.56 \pm 3.12^{\mathrm{ab}}$ \\
Diabetic+glibenclamide $\left(200 \mu \mathrm{g} \mathrm{kg}^{-1}\right)$ & $1.44 \pm 0.216^{\mathrm{abc}}$ & $7.68 \pm 1.23^{\mathrm{abc}}$ & $43.71 \pm 2.98^{\mathrm{abc}}$ \\
Diabetic+Chamomile recutita $\left(500 \mathrm{mg} \mathrm{kg}^{-1}\right)$ & $1.29 \pm 2.36^{\mathrm{abcd}}$ & $8.98 \pm 0.95^{\mathrm{abcd}}$ & $52.67 \pm 3.98^{\mathrm{abc}}$ \\
\hline
\end{tabular}

Values are given as Mean \pm SD and considered siniicant at $\mathrm{p} \leq 0.05$. a: Significantly different when compared to control group. b: significantly different when compared to to Ccontrol+ Chamomile recutita treated group. c: significantly different when compared to diabetic model group. d: Significantly different when compared to diabetic+ glibenclamide treated group 
Hassan Al-Musa and Fahaid AL-Hashem / American Journal of Pharmacology and Toxicology 9 (1): 1-12, 2014

Table 7. Levels of TBARS and activities of Superoxide Dismutase (SOD) and Glutathione Peroxidise (GPx) in the kidneys of the control and experimental groups of rats

\begin{tabular}{llll}
\hline & TBARS $(\mathrm{mmol} / \mathrm{mg})$ & $\mathrm{SOD}(\mathrm{U} / \mathrm{mg})$ & $\mathrm{GPx}(\mathrm{mmol} / \mathrm{min} / \mathrm{mL})$ \\
\hline Control & $0.789 \pm 0.017$ & $7.87 \pm 0.98$ & $67.16+3.89$ \\
Control+ Chamomile recutita $\left(500 \mathrm{mg} \mathrm{kg}^{-1}\right)$ & $0.678 \pm 0.009^{\mathrm{a}}$ & $11.34 \pm 1.04^{\mathrm{a}}$ & $78.45 \pm 7.34^{\mathrm{a}}$ \\
Diabetic control & $1.89 \pm 0.023^{\mathrm{ab}}$ & $3.46 \pm 0.093^{\mathrm{ab}}$ & $44.27 \pm 6.89^{\mathrm{ab}}$ \\
Diabetic + glibenclamide $\left(200 \mu \mathrm{g} \mathrm{kg}^{-1}\right)$ & $1.21 \pm 0.027^{\mathrm{abc}}$ & $5.67 \pm 0.45^{\mathrm{abc}}$ & $51.33 \pm 3.67^{\mathrm{abc}}$ \\
Diabetic + Chamomile recutita $\left(500 \mathrm{mg} \mathrm{kg}^{-1}\right)$ & $0.987 \pm 0.011^{\mathrm{abcd}}$ & $7.42 \pm 0.54^{\mathrm{abc}}$ & $60.37 \pm 3.98^{\mathrm{abcd}}$ \\
\hline
\end{tabular}

Values are given as Mean \pm SD and considered siniicant at $\mathrm{p} \leq 0.05$. a: significantly different when compared to control group. $\mathrm{b}$ : significantly different when compared to to Ccontrol+ Chamomile recutita treated group. c: significantly different when compared to diabetic model group. d: significantly different when compared to diabetic+ glibenclamide treated group

Histology of kidney in control animals or Chamomile recutita treated normal rats showed normal structure. In diabetic rats, kidney sections showed mild thickening of the basement membrane along with mild change in the density of mesenchyme, atrophy and degeneration of glomerular capillaries with increased Bowman's space (urinary space) and tubular necrosis. Some of the glumerulular capillaries were completely absent, in this group of rats The diabetic groups that were treated with Chamomile recutita $\left(500 \mathrm{mg} \mathrm{kg}^{-1}\right)$ or glibenclamide 200 $\mu \mathrm{g} \mathrm{kg}^{-1}$ ) showed improvement in their histological architectures including normal glomerulus, normal basement membrane and capillaries. Moreover, Bowman' s space (urinary space) and Acute Tubular Necrosis (ATN) were improved towards normal condition. However, the presence of some tubular necrosis was seen in the glibenclamide treated diabetic rats (Fig. 2).

\section{DISCUSSION}

The major findings o the present study is that Chamomile recutita flowers ethanolic extract is considered highly safe plants to animals and its administration causes significant reduction in blood glucose level in healthy normal and diabetic rats. Also, Chamomile recutita ameliorated the liver and kidney damage in streptozotocin induced diabetic rats as evidenced by amelioration of liver function enzymes, kidney function markers and decrease in the levels of lipid peroxidation, enhanced activity of endogenous antioxidant enzymes and improving of liver and kidney structure.

The results obtained from the acute and subacute toxicity studies showed that the ethanolic extract of Chamomile recutita flowers demonstrated high safety margin since the animals tolerated up to $10000 \mathrm{mg} \mathrm{kg}^{-1}$ body weight of the extract orally in the acute toxicity study and tolerated repeated doses up to $500 \mathrm{mg} \mathrm{kg}^{-1}$ for 28 days. According to the chemical labelling and classification of acute systemic toxicity, based on oral
LD50 value, which were recommended by OECD (2008), the ethanolic extracts of Chamomile recutita flowers were assigned as class 5 (LD50>2000 $\mathrm{mg} \mathrm{kg}^{-1}$ ), which was designated to have the lowest toxicity class. The high safety margin of the extract through oral route justified its widespread use by traditional healers.

In general, several studies have demonstrated that streptozotocin has a $\beta$-cell cytotoxic and slight carcinogenic effect, which significantly induced diabetes by damaging the cells that causes reduction in insulin release. The single high dose streptozotocininduced diabetic rat is one of the animal models of human Insulin Dependent Diabetes Mellitus (IDDM) or typeI diabetes mellitus. Our results have proved that the ethanolic extract of Chamomile recutita flowers has a potent significant hypoglycemic effect comparable to that of glibenclamide. It has been reported that glibenclamide produces the hypoglycemic effect by stimulating insulin secretion from $\beta$ cells of pancreatic islets (Ghosh and Suryawanshi, 2001; Tavafi et al., 2011). In the present study, oral administration of the ethanolic extract brought about a significant hypoglycemic effect in both normal control and streptozotocin induced diabetic rats at a dose of $500 \mathrm{mg} \mathrm{kg}^{-1}$ which represent daily human uptake in the middle east region. This hypoglycemic effect $o$ the extract was not accompanied by increase in serum insulin levels suggesting that the eventual mechanism responsible for the hypoglycemic effect of this plant may as a result of increased peripheral uptake of glucose, inhibition of hepatic glucose synthesis (Hamden et al., 2008; Dallak et al., 2009a; 2009b) or due to its strong antioxidant. Supporting to the later suggestion, indeed, it was reported that oxidative stress may have significant effect in the Glucose Transport Protein (GLUT) or at insulin receptor increasing serum glucose levels and scavengers of oxidative stress may have an effect in reducing the increased serum glucose level in diabetes (Jacqueline et al., 1997). 
These findings are in agreement to pervious researches carried out on different chamomile species or extracts. Kato et al. (2008) reported that chamomile tea drink has the ability to ameliorate the hyperglycemia and diabetic complications via suppressing blood sugar levels and increasing liver glycogen storage. Also, Eddouks et al. (2005) have reported a potent hypoglycemic effect of chamaemelum nobile extract in diabetic rats, an effect that is independent on insulin secretion. Moreover, further studies revealed protective effect of Matricaria chamomilla extract on pancreatic beta cells in diminishing hyperglycemia-related oxidative stress (Cemek et al., 2008).

However, evidences suggest that oxidative stress and free radicals play an important role in the pathogenesis of diabetes mellitus and diabetic complications including tissue damage (Zangiabadi et al., 2011). Oxidative stress results from an imbalance between radical-generating and radical scavenging systems, that is, increased free radical production or reduced activity of antioxidant defences or both. In diabetes, protein glycation and glucose autoxidation may generate free radicals, which in turn catalyse lipid peroxidation and tissue injury (Zangiabadi et al., 2011). Hence, it reveals that diabetic tissue injuries result from several agents and is not controllable only via inhibition of hyperglycemia (Liu et al., 2008). Namely, although in early stages of diabetes, tissues injuries are induced via hyperglycemia, their progress in latter stages are not related to hyperglycemia (Liu et al., 2008). Therefore, monitoring of blood glucose levels solely is not sufficient in retarding diabetes complications. Thus, a suitable drug must have both antioxidant and blood glucose decreasing properties (Ramesh and Pugalendi, 2006).

Liver enzymes such as AST, ALT, ACP and ALP are marker enzymes for liver function and integrity (Kim et al., 2006). These enzymes are usually elevated in acute hepatotoxicity or mild hepato-cellular injury (Kim et al., 2006). AST and ALT were used as markers to assess the extent of liver damage in streptozotocin induced diabetic rats (Kim et al., 2006). In addition to the assessment of AST and ALT levels during diabetes, the measurement of enzymatic activities of phosphatases such as Acid Phosphatase (ACP) and Alkaline Phosphatase (ALP) is of clinical and toxicological importance as changes in their activities are indicative of tissue damage by toxicants (Kim et al., 2006). In the current study, levels of ALT, AST and ALP were significantly increased in the serum of diabetic rats suggesting their leakage from damaged liver. Also, the diabetic hyperglycemia induced elevation in plasma levels of urea and creatinine, which are considered as the significant markers of renal dysfunction (Dallak et al., 2009a).

However, these biochemical results of liver and kidney dysfunction were matched with the altered pathologic findings. Histopathological evaluation of liver tissues of diabetic rats showed fatty changes in centrilobular portions of the livers with deformed hepatocytes. Also, morphological changes were seen in the section of the tested diabetic kidneys. Elevated level of liver enzymes, increased urea and creatinine and morphological changes in both liver and kidney suggest tissues damage due to extensive oxidative damage to liver and kidney in the experimental diabetic animals. This was evident by the significant decreases in the activities of the antioxidant enzymes, SOD and GPx and increase lipid peroxidation marker, TBARS.

In this study, the administration of ethanolic extract to Streptozotocin induced diabetic rats significantly reduces the elevated levels of AST, ALT, ALP, urea and creatinine levels, increased protein synthesis and ameliorated the morphological changes in both the livers and the kidneys of treated rats efficiently than glebinclamide. The improvement of the heato-renal morphology and function associated with treating the diabetic rats with the extract could be attributed to its antidiabetic action resulting in alleviation of altered metabolic status in animals and to its potent antioxidant potential resulting in membrane stability. Normal or diabetic rats treated with the extract showed enhanced levels of both SOD and GPx and reduced levels of lipid peroxides. Also, the excellent recovery of renal and hepatic function with treatment of the extract could be explained by the regenerative capability of the extract renal tubules and hepatocytes.

Major secondary components from M. chamomile belong to three different chemical classes: sesquiterpenes, coumarins and flavonoides (Emam, 2012). The major components of the essential oil are (-)R-bisabolol and R-farnesene and the yield of the essential oil from the flowers are about $0.4 \%$. This plant also has high levels of polyphenolic compounds such ascoumarins and flavonoides (Emam, 2012). The coumarins, herniarin, umbelliferone and esculetin make up approximately $0.1 \%$ of the total constituents. The major flavonoides components are apigenin, luteolin and quercetin, which comprise 16.8, 1.9 and 9.9\%, respectively, of total flavonoides (Emam, 2012). Thus, chamomile is one of the richest sources of dietary antioxidants which could explain their hepatoprotective 
effect on hepatorenal damage seen in diabetic rats. Supporting to this, There is substantial evidence that these compounds have suppressive activity on oxidative damage to skins, membranes, proteins and DNA by inhibiting free radical scavenging activity and contribute to protection against chronic health disorders such as atherosclerosis and hypertension (Emam, 2012).

\section{CONCLUSION}

In conclusion The current study clearly demonstrates that daily oral consumption of ethanolic extract of Chamomile recutita flowers not only exhibit a pronounced hypoglycemic effect but also reduce the lipid peroxidation process as well as enhance the antioxidant defence system in the liver and kidney of diabetic rats. These results suggest a promising selfmedication of hyperglycemia and diabetic complications. However, investigation of the chemical constituent the molecular analysis of this extract responsible for this hypoglycemic and antioxidant effect should be undertaken in order to confirm and clarify the mechanism behind this activity.

\section{ACKNOWLEDGMENT}

The author wish to thank Mr.Mahmoud Alkhateeb from Department of Physiology and Mr.Riyad Alessa from Department of Biochemistry at King Khalid University for their contributions to the current work.

\section{REFERNCES}

Akinnuga, A.M., O. Bamidele, O.A. Ebunlomo, O.S. Adeniyi and G.S. Adeleyea et al., 2010. Hypoglycaemic effects of dietary intake of ripe and unripe lycopersicon esculentum (tomatoes) on streptozotocin-induced diabetes mellitus in rats. OnLine J. Biol. Sci., 10: 50-53. DOI: 10.3844/ojbsci.2010.50.53

Al-Attar, A.M., 2010. Physiological study on the effect of acalypha wilkesiana leaves extract on streptozotocin-induced experimental diabetes in male mice. Am. Med. J., 1: 51-58. DOI: 10.3844/amjsp.2010.51.58

Cemek, M., S. Kaga, N. Simsek, M.E. Buyukokuroglu and M. Konuk, 2008. Antihyperglycemic and antooxidative potential of Matricaria chamomilla L. In streptozotocin-induced diabetic rats. J. Nat. Med., 62: 284-293. DOI: 10.1007/s11418-008-0228-1
Dallak, M., M. Al-Khateeb, M. Abbas, R. Elessa and F. Al-Hashem et al., 2009a. In vivo, acute, normohypoglycemic, antihyperglycemic, insulinotropic actions of orally administered ethanol extract of Citrullus colocynthis (L.) schrab pulp. Am. J. Biochem. Biotechnol., 5: 118-125. DOI: 10.3844/ajbbsp.2009.118.125

Dallak, M., N. Bashir, M. Abbas, R.E.M. Haidara and M. Khalil et al., 2009b. Concomitant down regulation of glycolytic enzymes, upregulation of gluconeogenic enzymes and potential hepatonephro-protective effects following the chronic administration of the hypoglycemic, insulinotropic citrullus colocynthis pulp extract. Am. J. Biochem. Biotechnol., 5: 153-161. DOI: 10.3844/ajbbsp.2009.153.161

Eddouks, M., A. Lemhadri, N.A. Zeggwah and J.B. Michel, 2005. Potent hypoglycaemic activity of the aqueous extract of chamaemelum nobile in normal and streptozotocininduced diabetic rats. Diabetes Res. Clin. Pract., 67: 189-195. DOI: 10.1016/j.diabres.2004.07.015

Emam, M.A., 2012. Comparative evaluation of antidiabetic activity of Rosmarinus officinalis $L$. and Chamomile recutita in streptozotocin induced diabetic rats. Agric. Biol. J. N. Am., 3: 247-252. DOI: 10.5251/abjna.2012.3.6.247.252

Ghosh, S. and S.A. Suryawanshi, 2001. Effect of Vinca rosea extracts in treatment of alloxan rats. Ind. J. Exp. Biol., 39: 748-759. PMID: 12018575

Gupta, A.K. and N. Misra, 2006. Hepatoprotective activity of aqueous ethanolic extract of chamomile capitula in paracetamol intoxicated albino rats. Am. J. Pharmacol. Toxicol., 1: 17-20. DOI: 10.3844/ajptsp.2006.17.20

Hamden, K., S. Carreau, S. Lajmi, D. Aloulou and D. Kchaou et al., 2008. Hyperglycaemia, stress oxidant, liver dysfunction and histological changes in diabetic male rat pancreas and liver: Protective effect of 17 beta-estradiol. Steroids, 73: 495-501. DOI: 10.1016/j.steroids.2007.12.026.

Jacqueline, M.S., L. Jongsoon and F.P. Paul, 1997. Tumor necrosis factor- $\alpha$-induced insulin resistance in 3T3-L1 adipocytes is accompanied by a loss of insulin receptor substrate-1 and GLUT4 expression without a loss of insulin receptor-mediated signal transduction. J. Biol. Chem., 272: 971-976. DOI: 10.1074/jbc.272.2.971 
Kato, A., Y. Minoshima, J. Yamamoto, I. Adachi and A.A. Watson et al., 2008. Protective effects of dietarychamomile tea on diabetic complications. J. Agric. Food. Chem., 56: 8206-8211. DOI: $10.1021 / \mathrm{jf} 8014365$

Khan, C.R. and Y. Shechter, 1991. Insulin, Oral Hypoglycemic Agents and the Pharmacology of the Endocrine Pancreas. In: Goodman and Gillman's The Pharmacological Basis of Therapeutics, Gillman, A.G., T.W. Rall, A.S. Nies and P. Taylor (Eds.), VIIIth Pergamon Press, New York, pp: 14631495.

Kim, J.S., J.B. Ju, C.W. Choi and S.C. Kim, 2006. Hypoglycaemic and antihyperlipidemic effect of four korean medicinal plants in alloxan induced diabetic rats. Am. J. Biochem. Biotechnol., 2: 154160. DOI: $10.3844 / a j b b s p .2006 .154 .160$

Liu, H.R., X.Y. Tang, D.Z. Dai and Y. Dai, 2008. Ethanol extracts of rehmannia complex (Di Huang) containing no Corni fructus improve early diabetic nephropathy by combining suppression on the ETROS axis with modulate hypoglycaemic effect in rats. J. Ethnopharmacol., 118: 466-472. DOI: 10.1016/j.jep.2008.05.015.

Lyra, R., M. Oliveira, D. Lins and N. Cavalcanti, 2006. Prevention of type 2 diabetes mellitus. Arq. Bras. Endocrinol. Metab., 50: 239-249. DOI: 10.1590/S0004-27302006000200010

OECD, 2002. Guidelines for the testing of chemicals/section 4: Health effects test no. 423: Acute oral toxicity-Acute toxic class method. Organization for Economic Cooperation and Development, Paris, France.
OECD, 2008. Guidelines for the testing of chemicals/ no. 407: Repeated dose oral toxicity test method. Organization for Economic Cooperation and Development, Paris, France.

Ramesh, B. and K.V. Pugalendi, 2006. Impact of umbelliferone (7-hydroxycoumarin) on hepatic marker enzymes in streptozotocin diabetic rats. Ind. J. Pharmacol., 38: 209-210.

Singh, O., Z. Khanam, N. Misra and M.K. Srivastava, 2011. Chamomile (Matricaria chamomilla L.): An overview. Pharmacogn. Rev., 5: 82-95. DOI: 10.4103/0973-7847.79103

Srivastava, J.K. and S. Gupta, 2007. Antiproliferative and apoptotic effects of chamomile extract in various human cancer cells. J. Agric. Food Chem., 55: 9470-9478. DOI: 10.1021/jf071953k

Tavafi, M., H. Ahmad, A. Tamjidipoor B. Delfanc and A.R. Khalatbarid, 2011. Satureja khozestanica essential oil ameliorates progression of diabetic nephropathy in uninephrectomized diabetic rats. Tissue Cell, 43: 45-51. DOI: 10.1016/j.tice.2010.11.004

Zangiabadi, N., V. Sheibani, M. Asadi-Shekaari, M. Shabani and M. Jafari et al., 2011. Effects of melatonin in prevention of neuropathy in STZinduced diabetic rats. Am. J. Pharmacol. Toxicol., 6: 59-67. DOI: 10.3844/ajptsp.2011.59.67

Zeggwagh, N., A. Sulpice and T.M. Eddouks, 2007. Anti-hyperglycaemic and hypolipidemic effects of ocimum basilicum aqueous extract in diabetic rats. Am. J. Pharmacol. Toxicol., 2: 123-129. DOI: 10.3844/ajptsp.2007.123.129 